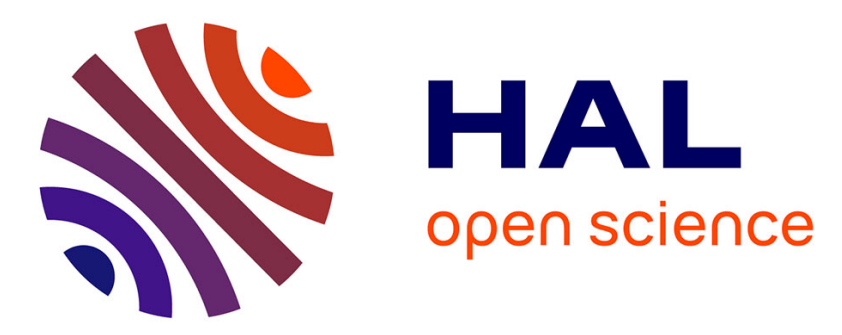

\title{
Buyer Engagement and Labour Conditions in Global Supply Chains: The Bangladesh Accord and Beyond
}

\author{
Chikako Oka, Niklas Egels-zandén, Rachel Alexander
}

\section{To cite this version:}

Chikako Oka, Niklas Egels-zandén, Rachel Alexander. Buyer Engagement and Labour Conditions in Global Supply Chains: The Bangladesh Accord and Beyond. Development and Change, 2020, 51 (5), pp.1306-1330. 10.1111/dech.12575 . hal-02952114

\section{HAL Id: hal-02952114 \\ https://hal.science/hal-02952114}

Submitted on 29 Sep 2020

HAL is a multi-disciplinary open access archive for the deposit and dissemination of scientific research documents, whether they are published or not. The documents may come from teaching and research institutions in France or abroad, or from public or private research centers.
L'archive ouverte pluridisciplinaire HAL, est destinée au dépôt et à la diffusion de documents scientifiques de niveau recherche, publiés ou non, émanant des établissements d'enseignement et de recherche français ou étrangers, des laboratoires publics ou privés. 


\title{
Buyer Engagement and Labour Conditions in Global Supply Chains: The Bangladesh Accord and Beyond
}

\author{
Chikako Oka*, Niklas Egels-Zandén and Rachel Alexander
}

\section{Forthcoming in Development \& Change}

\begin{abstract}
The Accord on Fire and Building Safety in Bangladesh ('the Accord') has received both praise and criticism concerning its implications for corporate responsibility and power. This article contributes to the debate by situating the Accord within a broader set of activities that buyers are engaged in to promote better labour conditions in their supply chains. The authors identify three approaches of buyer engagement: auditing, capacity building and advocacy. Drawing on interviews conducted with European brands and retailers, the article shows how buyers perceive the merits and challenges of these approaches, and whether and how they discharge responsibility and power through these activities. The study shows that the Accord is seen primarily as part of the auditing approach with a key feature being its use of collective leverage as a means of enforcement. While greater buyer power has not necessarily been accompanied by greater responsibility, the article highlights heterogeneity among buyers in how they take up different approaches, painting a more nuanced picture of buyer responsibility and power.
\end{abstract}

\footnotetext{
*Corresponding author

We thank the anonymous reviewers and editor for their valuable guidance and Sarah Ashwin and Elke Schüßler for helpful comments on earlier versions of this article. We are very grateful to Elke Schüßler and Nora Lohmeyer for sharing their German interview data. We gratefully acknowledge funding by the Volkswagen Foundation for the project 'Changes in the Governance of Garment Global Production Networks: Lead Firm, Supplier and Institutional Responses to the Rana Plaza Disaster' under the European and Global Challenges Programme.
} 


\section{INTRODUCTION}

The Bangladesh Accord on Building and Fire Safety (hereafter, the Accord) that emerged in the aftermath of the Rana Plaza disaster in 2013 has been hailed by some as a breakthrough and a game-changer, given its embedded legal liability (Anner et al., 2013) and labourinclusive nature (Donaghey and Reinecke, 2018). Others question whether it really is a paradigm shift, given that it reproduces corporate power (Scheper, 2017) and serves as a white-washing tool for corporations (Salminen, 2018). The Accord thus reflects the ongoing broader debate on corporate responsibility and power in global supply chains.

In this debate, we hear little of what buyers think about the Accord and how they situate it in relation to their engagement with other activities aimed at better labour conditions in their supply chains. The Accord, however exceptional and novel its origin, governance and legal implications may be, is just one of many corporate social responsibility (CSR) activities for global firms. Indeed, the Accord is rather limited in terms of issue scope (i.e. building and fire safety) and geography (Bangladesh), while global buyers are pressed to engage in a wider range of sustainability issues in their global supply chains. In this article, therefore, we seek to understand the Accord and its significance (or lack thereof) by situating it among a broader set of buyer activities aimed at improving labour conditions in their supply chains.

To complement the other two articles in this special section, which cover workers' and factory managers' perspectives, we delve into buyers' perspectives by drawing on 130 interviews with CSR managers, procurement managers and corporate strategy managers representing 64 garment firms headquartered in Germany, Sweden and the UK. We ask how the Accord fits into the overall tool kit of buyer engagement, and how buyers perceive the benefits and challenges of these activities. In light of the ongoing debate on buyer responsibility and power concerning the Accord, we will also examine how buyers discharge responsibility and power as they engage in different types of activities. In so doing, we aim to contribute to a better and more nuanced understanding of buyers' motivations and constraints, and the implications of these on corporate responsibility and power more broadly.

The rest of the article proceeds as follows. We open with a literature review which situates the Accord in the scholarly debate on buyer responsibility and power and discusses the three 
approaches employed by buyers: auditing, capacity building and advocacy. We then provide an overview of the garment retail landscape in Germany, Sweden and the UK, and discuss the data and methods of our study. The empirical section locates the Accord in relation to the three approaches and shows how buyers perceive the relative merits and demerits of each approach, as well as addressing how buyer power and responsibility manifest themselves. This is followed by a discussion which draws out key findings related to the three approaches, and a conclusion which highlights contributions and policy implications, notably the need to level the playing field so that all buyers will be compelled to assume greater responsibility.

\section{BUYER RESPONSIBILITY, POWER AND THE ACCORD}

Global firms sourcing from developing countries are often seen as accountable for ensuring fair working conditions in their supplier facilities. This expectation is based on two key assumptions. One is that buyers are, at least partly, responsible for suppliers' working conditions. The second is that these buyers have the power to regulate labour conditions in their supply chains.

Buyer responsibility for supply chain practices has evolved from denial and rejection in the 1980s, through reluctant acknowledgment and development of corporate codes of conduct (CoCs) and auditing in the1990s, to a more proactive engagement by buyers in the past decade (Schrempf-Stirling and Palazzo, 2016). Against the background of activist campaigns and pressure, firms sourcing from poorly regulated environments have been compelled to close a regulatory gap (Gereffi and Mayer, 2005). This process can be seen to be shifting responsibility from public institutions to private corporations.

Call for greater buyer responsibility is often based on the assumption that buyers wield overwhelming power vis-à-vis suppliers and producing-country governments. Development and geography scholars tend to highlight uneven power relations and asymmetries between powerful and concentrated lead firms in the North and suppliers scattered in the global South (Coe et al., 2008; Nadvi, 2008; Tokatli, 2007). Such power asymmetries and conflicting demands placed on suppliers underlie the anxieties and frustrations expressed by suppliers in the South (Rahman and Rahman, this issue; see also Ruwanpura and Wringley, 2011). 
However, others argue that buyers are less powerful than commonly assumed and have limited leverage vis-à-vis suppliers. First, buyers do not necessarily hold the balance of power in individual buyer-vendor relationships (Alexander, 2019a). For example, many Tier 1 suppliers are no longer captive, dependent or subservient as they are now themselves large multinationals with multiple subsidiaries and capable of offering a full package of services (Azmeh and Nadvi, 2014; Merk, 2014). Second, factory managers facing contradictory and unrealistic buyer demands can engage in evasion, actively circumventing and disrupting institutional pressure through various means (Alexander, 2019a; Soundararajan et al., 2018). Third, intermediaries such as sourcing agents can dilute and limit buyer power (Oka, 2010; Soundararajan and Brown, 2016).

The question of buyer responsibility and power is at the heart of the debate surrounding the Accord. The Accord is seen by some as a game changer given its labour-inclusive governance, embodying industrial democracy (Donaghey and Reinecke, 2018) and transnational industrial relations arrangement (Ashwin et al., forthcoming). Moreover, the Accord's legally binding nature has been heralded a breakthrough, paving the way for joint liability in global supply chains (Anner et al., 2013). On the other hand, the Accord is criticized for not changing power relations and for becoming a self-serving tool for corporations. Here, the Accord is not seen as a paradigm shift because it reproduces transnational corporate buying power (Scheper, 2017) and it lacks shared responsibility on the part of buyers (Barrett et al., 2018). Moreover, some legal scholars argue that buyers can control liabilities arising from the legal binding nature of the Accord while taking advantage of white-washing effects vis-à-vis consumers and regulators (Salminen, 2018).

In this debate, buyers' perspectives have been largely lacking; where they are mentioned, they are often portrayed as irresponsible and greedy capitalists who only care about their own interests. However, we are starting to see work emerging that examines buying firms' perspectives and how they have reacted to the Rana Plaza disaster, how they have engaged in the Accord and what has come out of the process. For example, scholars have shown that the Rana Plaza as a focusing event had greater effects on followers and laggards rather than on leading garment firms (Schüßler et al., 2019), impacting on how buyers have constructed varying CSR identities (progressives vs. conservatives) as they engaged in the Accord process (Huber and Schormair, 2019), and have shown how a group of progressive firms 
created trust among themselves and with unions through the Accord that spilled over to another collective and union-inclusive initiative, ACT (Ashwin et al., forthcoming). ${ }^{1}$

What still remains unexplored in the literature are buyers' perspectives in terms of how they view the Accord vis-à-vis other activities they engage in, the relative merits and demerits, as well as how buyers discharge their responsibility and power through a range of activities (one being the Accord) in the post Rana Plaza era. It is important, therefore, to situate the Accord in relation to other activities that buyers are engaged in to improve labour conditions in their supply chains.

\section{THREE APPROACHES OF BUYER ENGAGEMENT}

Drawing on the literature, we identify three main approaches that buyers use to promote positive changes in supply chain labour conditions: auditing, capacity building and advocacy.

Auditing has been at the centre of the corporate response to growing pressures for buyers to address poor working conditions in their supply chains (Bartley, 2003; O'Rourke, 2003). The system generally involves buying firms setting CoCs, having suppliers audited by internal or external auditors, and demanding remediation when violations are found. The auditing approach has been adopted by almost all major multinationals, making social auditing a US\$ 80 billion industry (AFL-CIO, 2014). The auditing approach thus comprises three aspects - standards, audits and enforcement - each of which can pose different challenges. Unilateral standards set by corporations have been criticized as weak and unaccountable (Jenkins et al., 2002). Although this issue is increasingly being addressed as CoCs converge toward industry standards or the base codes of multi-stakeholder initiatives (MSIs), such as Amfori Business Social Compliance Initiative (BSCI) or Ethical Trading Initiative (ETI) base codes, fragmentation continues in the garment industry's private auditing systems (Turcotte et al., 2014). Audits, meanwhile, are often found to be unreliable because of the quality of auditors (LeBaron and Lister, 2015), because not all issues are amenable to auditing (Barrientos et al., 2011), and because suppliers can engage in all sorts of dubious practices to hide non-compliance (Raworth and Kidder, 2009). Lastly, enforcement of remediation is not

\footnotetext{
${ }^{1}$ For more on the ACT initiative, see the website: https://actonlivingwages.com/
} 
straightforward. Locke et al. (2009) call it 'an open secret' that brands rarely stop working with factories due to compliance issues and they may not have enough leverage to enforce needed changes. These challenges explain the generally disappointing impact of CoCs and auditing on labour rights and working conditions in global supply chains (Egels-Zandén and Lindholm, 2015; Locke, 2013).

Given the limits to the auditing approach, a different system which emphasizes commitment and cooperation has been proposed as a promising alternative. Locke et al. (2009) argue that a commitment-based model characterized by information sharing, trust building and problem solving between auditors, suppliers and buyers can address deep-seated problems that the traditional compliance model could not. Lund-Thomsen and Lindgreen (2014) identify a shift (at least in discourse) from a compliance paradigm based on policing to a cooperative paradigm with seemingly higher levels of shared responsibility for addressing labour challenges. One of the core features of the cooperative paradigm is capacity-building support from buyers for their suppliers (ibid.). Capacity building can take various forms, from training suppliers in sustainability standards (Riisgaard et al., 2019), to empowering workers, for instance through the HerProject initiated by Business for Social Responsibility, ${ }^{2}$ and introducing lean production techniques in supplier facilities (Distelhorst et al., 2017). Buyers can use capacity-building approaches to address diverse and sometimes more complex challenges that producers face (Alexander, 2019b). Nonetheless, trade-offs and tensions between auditing and capacity building have been documented at the level of implementation (Riisgaard et al., 2019).

The third approach, advocacy, has received scant attention in the literature on global supply chains. While there is emerging research on 'responsible lobbying' seeking to promote social good through public policy means (Anastasiadis et al., 2018), such phenomena in developing country contexts have been neglected. Although brands are often portrayed as culprits, some of them are playing the role of labour rights advocates. Oka's (2018) work on brand advocacy draws attention to such political activities carried out by buyers, who pressure producercountry governments to take pro-worker actions. Drawing on social movement theory, Oka shows how issue salience, mobilization structures, political opportunities and context, and resource dependence of actors shape the likelihood and success of brands' collective political

\footnotetext{
${ }^{2}$ For more information, see: https://herproject.org/
} 
action. In this nascent field, there is still much that is unknown. Who is involved in these activities? What are the merits and demerits of advocacy as perceived by brands? In this article, we expand the scope of brand advocacy to include advocacy vis-à-vis buying-country governments as well as producing-country governments.

These three approaches can be combined and used simultaneously, and some initiatives can involve all three types of activities. For instance, Amfori BSCI, a business-driven initiative, has all three elements as it coordinates auditing, proposes capacity building, and engages in advocacy vis-à-vis political actors. In our empirical findings, we examine buyers' perceptions of each type of engagement.

\section{CONTEXT, DATA AND METHOD}

This article focuses on understanding the ways that European buyers perceive their roles in governing labour conditions in their supply chains. To learn about buyers' perspectives, we conducted semi-structured interviews with CSR managers, procurement managers and corporate strategy managers. Overall, the article draws on interviews with representatives of 64 European firms. All of the firms had an annual revenue of over 30 million euros in 2015/16, and were among the largest domestically owned apparel brands and retailers in their respective countries in terms of revenue. The interviews were conducted between 2015 and 2019, and include 54 interviews with 22 German firms that rank, based on revenue, in the domestically owned top 70; 33 interviews with 21 Swedish firms that rank in the domestically owned top 30; and 43 interviews with 21 British firms that rank in the domestically owned top 100. Between one and five interviews were conducted per firm. Additionally, the authors attended over 30 industry events during this period, where related topics were discussed.

The home countries of the firms interviewed for this study all have large apparel retail markets; in 2018, these were worth US\$ 66 billion in Germany, US\$ 9 billion in Sweden, and US\$ 60 billion in the UK. Within these countries, there is a high level of concentration of sales within a small group of companies: the retail market share of the top 20 companies in 
2018 was 34 per cent in Germany, 47 per cent in Sweden, and 36 per cent in the UK. ${ }^{3}$ A list of the top 20 garment retailers in each country is provided in Appendix Table A.1. In all three countries, most retail has traditionally taken place through clothing specialists (see Figure 1). However, the popularity of clothing specialists is decreasing with the growth of supermarkets in the apparel sector, especially in the UK (Marketline 2018c), and of online retail, which has already captured a significant share of the clothing market in Germany (Marketline, 2018a).

[Figure 1 about here]

Considering the largest domestic firms in each country, there are significant differences among the three countries studied. The UK and Germany are home to many large companies, with both having 20 or more domestically owned garment sellers with over US\$ 1 billion turnover in $2015 / 16^{4}$. With the exception of H\&M, most Swedish brands are smaller than those in the UK and Germany. Firms based in each of these countries often interact with other domestic firms in various national forums (e.g. ETI in the UK, the Swedish BSCI national chapter, BSCI in Germany). National histories of industrial relations prior to the trend of outsourcing have been found to play a role in shaping contemporary labour governance institutions and norms in these countries (Alexander et al., 2019). Large brands and retailers in each of the countries have similar models which involve designing and marketing domestically, and largely relying on independent suppliers to carry out production. Table 1 shows the top five sources of garment imports for each country in 2018. As can be seen, Bangladesh is an important sourcing location for each European country in this article.

[Table 1 about here]

Interview transcripts were coded using Nvivo qualitative analysis software to identify portions of text in which respondents discussed benefits, challenges, power, responsibility and the three categories of activities - auditing, capacity building and advocacy. The authors systematically reviewed these passages to identify key perceptions emerging from the interviewees' responses in order to better understand buyers' perspectives.

\footnotetext{
${ }^{3}$ Data from the Euromonitor online database, 'Passport': https://www.portal.euromonitor.com/portal/magazine/homemain [7/22/2019]

${ }^{4}$ Data from Changes in the Governance of Garment Global Production Networks: Lead Firm, Supplier and Institutional Responses to the Rana Plaza Disaster project database. https://www.wiwiss.fuberlin.de/forschung/Garments/index.html
} 


\section{EMPIRICAL FINDINGS}

\section{Auditing}

The vast majority of firms in our sample have either internal or external staff auditing their suppliers' labour conditions. Despite its widespread use, CSR managers are well aware of the limitations of social auditing in bringing substantial progress to the lives of workers:

If you look at auditing, 60 billion a year is spent on auditing, it means nothing, right, because if you look at what we've achieved, you know, workers' wages have gone down by like 30 per cent in the last five years. Ours have gone up by 25 per cent. So we've not made lives better through auditing because again, it is just that snapshot ... it's just a piece of paper they can hide behind. ${ }^{5}$

While few companies are considering a shift away from auditing to capacity-building, no firm in our sample was willing to abandon auditing. This approach remains a cornerstone for many companies, as it gives them a sense of control. As one brand representative put it: 'I cannot see that we would ever stop with auditing. You have to have some form of control function'. ${ }^{6}$ Another CSR manager says that auditing gives some sort of guidelines, despite its limitations:

So whilst there's, these days, quite a lot of negativity around auditing, it still does have its purpose. We never take it as gospel, per se. It's a snapshot in time. It's as good as the person who conducted that audit on that particular day and the people who were present in the factory, cooperation, non-cooperation, accessibility to records and documents and so forth but it does give us an indication and a good guideline. ${ }^{7}$

One of the challenges of the auditing approach (apart from standards and audits themselves) is how to create incentives for suppliers to remediate. Although the need is very much felt, very few brands claim to have integrated compliance performance in sourcing decisions, as illustrated by one procurement manager:

\footnotetext{
${ }^{5}$ CSR Manager, UK Firm 02, interview 21 September 2016.

${ }^{6}$ CSR Manager, Swedish Firm 07, interview 19 September 2016.

${ }^{7}$ CSR Manager, UK Firm 04, interview 12 January 2017.
} 
I guess the challenge for us is, it's great that factories are hitting all of their compliance targets, but commercially they're not getting the orders. It's actually, 'How do you reward the good behaviour with orders?' ... which I think is what we're trying to figure out now from a sourcing and quality perspective, that we can give something back to those good suppliers. ${ }^{8}$

While carrots are rarely provided, even sticks are not very effective in many cases. Most of the brands and retailers we interviewed say they have different degrees of leverage vis-à-vis supplier manufacturers, depending on the nature of their relationship (e.g. length, share of capacity). They sometimes lack clout to get their supplier factories to implement remediation, as one CSR manager explains: 'So the manufacturer partly failed to push it through because he did not necessarily depend on our orders and made it relatively clear that he was not willing to implement these standards. In general, this leads us to say goodbye to that manufacturer'?

However, the threat to stop sourcing from the factory does not always give a sufficient incentive for suppliers to address violations, as another buyer comes in to replace them. This lack of leverage by individual buyers is especially salient in Bangladesh, where suppliers' production capacity is often very large, making it difficult for individual buyers to wield influence, as several buyers remarked. One option for smaller brands lacking leverage is to call on other larger brands to put things right, as one CSR manager explains:

Who else is in that factory? Because if we're in there with H\&M, if push comes to shove I can just call H\&M and say 'hey, can you help us with this?' and H\&M will then, you know, if I tell H\&M this factory you know is not paying overtime, H\&M will be outraged and they're bigger than we are in most cases, so they will go and make the factory pay overtime. ${ }^{10}$

In fact, the Accord has helped institutionalize such ad hoc inter-brand cooperation: for each factory, one brand (often the most important buyer in the factory) is nominated to take a lead in following up on remediation with the factory. While this can result in fruitful cooperation among brands, it can also encourage free-riding by smaller brands participating in the Accord.

\footnotetext{
${ }^{8}$ Procurement Manager, UK Firm 07, interview 17 February 2017.

${ }^{9}$ CSR Manager, German Firm 06, interview 6 June 2016.

${ }^{10}$ CSR Manager, German Firm 07, interview 13 June 2016.
} 
While the Accord is essentially an auditing approach, its key features lie in setting common standards, sharing common auditing systems and, most importantly, collective enforcement. While common standards and auditing systems have reduced auditing duplication and helped focus factories on remediation, the potential for collective response by over 200 buyers has enhanced buyer leverage. Several brand representatives mentioned that the Accord has helped expand their network and collaboration with other brands beyond their national network:

'What I think it has influenced greatly is what can be achieved collaboratively in the wake of ... the Accord ... working together. My network with ethical compliance people had always been limited to the ETI. I can tell you all my equivalents in all the big brands in the UK .... Now my closest allies would be in Germany, for instance'. ${ }^{11}$

The situation is somewhat different in Sweden with the vast majority of firms stating that while the Accord did create space for inter-brand meetings, this has not translated into any indepth meaningful international collaboration. This is partly due to the fact that, with the exception of H\&M, Swedish brands are fairly small and less global than their counterparts in Germany and the UK; they tend to let H\&M take the lead in global discussions and initiatives while they restrict themselves to Swedish circles:

In the beginning there was a lot with the Accord. You got bombarded with emails. There were meetings with other brands and factory managers to discuss how to solve issues .... Now it has settled down as we have elected representatives to discuss and negotiate with unions and other stakeholders. We now mainly have contact with the Swedish brands that we know from other initiatives as well. ${ }^{12}$

In general, however, the growth of inter-brand networks and collaboration has translated into a greater collective leverage vis-à-vis suppliers. One brand representative described the weight of a collective compliance approach as follows:

The thing with the Accord is obviously it kind of links in with the national action plan, and if somewhere was unsafe, then the combined weight of 200 buyers all saying we're not going to work with you, unless you do A, B, C, whatever, focuses a bit more attention by those suppliers who perhaps before might have been more tempted

\footnotetext{
${ }^{11}$ CSR Manager, UK Firm 01, interview 16 September 2016.

${ }^{12}$ CSR Manager, Swedish Firm 08, interview 20 December 2016.
} 
to go well, actually I don't mind about losing this customer, I've got all these other ones. $^{13}$

This is in line with the findings of Rahman and Rahman (this issue), showing how factory managers view and employ the concentrated power of buyers which has resulted from the Accord and another similar initiative, the Alliance for Bangladesh Worker Safety. The question then is how buyers view their responsibility for remediation once auditing identifies certain deficiencies. Of the firms that we interviewed that source from Bangladesh, almost half said they assist suppliers in conducting rigorous reviews of safety standards, around a third said they assist suppliers in setting up or maintaining workplace safety committees, and about one in ten said they have purposefully paid higher prices to support factory improvements.

Very few of the buyers we interviewed shared the actual cost of remediation with their suppliers. Many buyers felt that it was not their responsibility to pay for factory improvements; some also stated that factory owners themselves say they do not want the buyers to 'own' their factory's machinery or equipment. A few buyers, especially from Swedish firms, said that they were paying a purchasing price that should allow factory management to cover such costs themselves, adding that 'We are really nice when it comes to prices. We do not pressure purchasing prices like maniacs like many other brands do and we have gained a reputation that we can be trusted' ${ }^{14}$ Moreover, a few brand representatives pointed out that Bangladeshi factory owners do have 'resource slack', as evidenced by their Porsche cars, Rolex watches and helicopters.

The non-corporate participants [of the Accord] are obsessed with making the companies pay for the remediation, even though, you know, the factory owners, well we made a list how we knew that our factories would be able to pay for their remediation project and one of the criteria we used was, does the owner own a helicopter. You know, so these poor third world people they may have to delay buying their fourth apartment in London in order to pay for the Accord. ${ }^{15}$ Other brand representatives were more circumspect about the apparent riches of Bangladeshi factory owners, recognizing financial difficulties that many of them are facing.

\footnotetext{
${ }^{13}$ CSR Manager, UK Firm 03, interview 6 December 2016.

${ }^{14}$ CSR Manager, Swedish Firm 17, interview 10 December 2016.

${ }^{15}$ CSR Manager, German Firm 07, interview 13 June 2016.
} 


\section{Capacity Building}

While buyers tend to eschew shouldering the direct cost of remediation, they appear to be more willing to invest in capacity-building activities. One CSR manager said 'We tend not to just give money direct. It's always money for, you know ... the training programme or resources support rather than actually just giving cash over to a factory'. ${ }^{16}$ Indeed, capacity building is increasingly seen as a promising alternative or complement to traditional auditing. Given that auditing and capacity building normally come from the same CSR budget, however, there is a trade-off between these activities. One of the consequences of the Accord to some (especially medium size) brands is that the CSR budget has been diverted to the Accord at the expense of other CSR work, including capacity building: 'We basically ended up dropping a lot of other CSR work in order to do the Accord work. And you know it's important to understand how fundamentally different from social compliance the Accord is. You know only now they're trying to add on a training component to the Accord'. ${ }^{17}$

While small or medium-sized firms found the Accord-related expenses rather high, for larger firms the Accord fees are more manageable. When asked whether they have reduced other CSR work because of the resources allocated for the Accord work, one brand responded 'No, no, definitely not, definitely not. Because [the Accord] membership fees are of manageable magnitude for a company of our size, to be totally honest'. ${ }^{18}$ Despite the trade-offs, many CSR managers spoke of the need to engage in capacity building to address deeper issues and bring about change. One interviewee stated, 'Today you have to do development and education if you want to achieve any form of change. If not, you could audit every year but it will not lead to any form of change'. ${ }^{19}$ Moreover, engaging in capacity-building projects allows them to 'tell nice stories' in their CSR reports, as one manager candidly admitted. ${ }^{20}$

Capacity building takes two main forms. Some capacity building is designed as part of ongoing auditing approaches, such as supplier induction training when a new relationship

\footnotetext{
${ }^{16}$ CSR Manager, UK Firm 04, interview 12 January 2017.

${ }^{17}$ CSR Manager, German Firm 07, interview 13 June 2016.

${ }^{18}$ CSR Manager, German Firm 06, interview 6 June 2016.

${ }^{19}$ CSR Manager, Swedish Firm 07, interview 19 September 2016.

${ }^{20}$ CSR Manager, UK Firm 05, interview 16 May 2019.
} 
begins with a factory. The Accord is an auditing programme that has an element of capacity building as training is provided to joint labour-management safety committees. However, other capacity-building programmes are designed as stand-alone initiatives that may be targeted at a particular issue and are often implemented through pilot projects. An example is HerProject, aiming at better worker health and empowerment, especially for women, coordinated by Business for Social Responsibility.

In terms of buyer-supplier relationships, capacity building involves a longer-term commitment with more frequent interactions than auditing requires. Many firms in this study claim to be shifting from short-term transactional relationships to longer-term relationships with fewer suppliers. Although partnership is emphasized, asymmetrical power and subtle coercion remain an important part of getting suppliers to join programmes specifically focused on capacity building. Buyers tend to urge their strategic suppliers to join these programmes based on the understanding that it is a necessary part of doing business, as one CSR manager explains: 'Right now we are trying to get our largest supplier in Bangladesh involved in HERproject. We are just getting started but they [the supplier management] understand that this is really important and see this as part of their business'. ${ }^{21}$

Despite the growing interest and excitement about how capacity building can address rootcause issues (which auditing cannot), the reality is that not all brands are actively involved or willing to invest. And when they do, they often target their strategic suppliers in selected countries, limiting the reach and impact. A German CSR manager stated: '[most brands] don't want to go beyond auditing initiatives, because auditing is sufficient for their business model. Say you're a US brand and you're concerned about suppliers from a liability point of view, and you are relatively mid-range or smaller, you won't invest in any of these other types of capacity programmes'. ${ }^{22}$ One of the interviewees from a UK firm commented: 'We've got many other programmes that are happening within factories beyond compliance that our teams are kind of ... in and out of ..., particularly our strategic suppliers, which is probably around 20 per cent'. ${ }^{23}$

\footnotetext{
${ }^{21}$ CSR Manager, Swedish Firm 12, interview 12 October 2016.

${ }^{22}$ CSR Manager, German Firm 06, interview 8 May 2017.

${ }^{23}$ CSR Manager, UK Firm 14, Interview 4 October 2017.
} 


\section{Advocacy}

The third of the approaches, advocacy seeks to bring about change at the industry and/or national level, in producing and/or buying countries. Most firms in our sample have been engaged in some sort of advocacy activities, often by way of their membership in MSIs or business associations. One UK firm representative pointed out that businesses need to go beyond the compliance mode and engage with government actors to address systemic challenges:

We have to be able to call it out when it's a particular problem. For example ... when we're talking about migration and things like that. Is that a government issue? Is it a business issue? Is it both? Where do people start to work together? The agenda is advancing so much and we can't just stick in this compliance, labour standard world. $^{24}$

In Bangladesh, as well as in other garment-producing countries, some leading brands have been engaged in advocacy, which may be ad hoc or more institutionalized. Ad hoc advocacy can take the form of boycotts, letter writing and face to face meetings with government officials. For instance, in February 2017 a group of brands threatened to boycott the Dhaka Apparel Summit - a flagship event organized by the Bangladesh Garment Manufacturers and Exporters Association (BGMEA) — in response to the violent crackdown on striking workers in the garment factories of Ashulia in December 2016. C\&A, Gap, H\&M, Inditex, Next, Tchibo and VF Corporation announced their intention of not participating in the Summit, expressing their concern at the government's handling of the labour unrest (MacCarthy, 2017). This threat of boycott led to the immediate release of detained activists.

Many of our interviewed brands have written or signed letters to governments expressing concerns or demanding changes to labour rights, laws or wages. Under pressure by activist campaigns, global brands have urged the Bangladeshi government to raise the minimum wage on several occasions, the latest of which was the round of wage talks in summer 2018 (Russell, 2018). One Swedish brand which had signed letters to the Bangladeshi government asking for higher minimum wages in the past recounted: 'We have been part of a group writing letters to the government in Dhaka about raising the minimum wage and that we will

${ }^{24}$ CSR Manager, UK Firm 14, interview 11 October 2017. 
continue to source from Bangladesh. Hopefully, this was one of the things that led to the recent wage increase'. ${ }^{25}$ However, one CSR manager experienced in dealing with government officials questions the benefit and impact of signing letters, arguing that local presence and close contact are crucial:

It's very interesting when you work directly with government as I do, I talk to ministers, see how brands that are local and on the ground, this is what we try to do, you need to have local insights and local mobility. It's very different to people who sit back say in London and write letters. I'm a bit critical that letters sometimes don't achieve anything. It makes you feel good you sign on it. If you really want to have effective influence and action, you need to engage with officials in a very close way. ${ }^{26}$

A few buyers engage in ad hoc advocacy through meetings with government officials. For example, the CEO of H\&M has met with key government figures in Bangladesh on several occasions and held public press conferences afterwards explaining the reasons for the meetings. ${ }^{27}$ Nonetheless, such political activities are often reserved for very large buyers with important presence and clout in the producer country. One relatively large German retailer explains: 'But you don't have more influence than that. And I can't sit down with the prime minister of Bangladesh or someone else and say "You should XYZ". H\&M might be able to do that. It is told that by now, they've got 800 people in the office in Dhaka'. ${ }^{28}$

While brands' responses to unfolding events are largely ad hoc, there is increasing institutionalization of brand advocacy. The Accord has an element of advocacy, as its implementation, maintenance and survival involve extensive lobbying on the part of brands vis-à-vis the Bangladeshi government and the BGMEA, according to one long-time member of the Accord steering committee. ${ }^{29}$ Brands' collective leverage was crucial in getting the powerful industry association to listen, as one manager recounts:

But it [collective leverage] also put massive pressure, thank God, on the industry association, the BGMEA, which are ... I mean they're all factory owners; they're all involved in parliament as well. They're not exactly the nicest people in the world but it made them have to take notice and get involved and say, 'Okay, well we're going to

\footnotetext{
${ }^{25}$ CSR Manager, Swedish Firm 04, interview 16 December 2016.

${ }^{26}$ CSR Manager, German Firm 06, interview 8 March 2017.

${ }^{27}$ For example, in September 2012, as reported by Radio Sweden, 5 September 2012.

${ }^{28}$ Procurement Manager, German Firm 02, interview 20 April 2016.

${ }^{29}$ Informal talk at an industry event, 13 February 2019.
} 
have to take this seriously', because if they didn't, then brands would have had to pull back. They would have lost that sourcing. ${ }^{30}$

Another example of institutionalized advocacy is the ACT initiative, which involves a coalition of global garment firms seeking to promote industry-wide collective bargaining agreements in key garment-producing countries (Ashwin et al., forthcoming). The basic idea of ACT is to get industry associations, unions and governments to negotiate a living wage that applies to the whole industry, on a country-by-country basis. Here, collective leverage becomes even more indispensable, as highlighted by one ACT-member brand representative: Actually, we need everybody .... So some of the collaborations that we do will really, really work because actually, we have the power of huge retailers saying, 'You know what, Mr Government Official, you need to do the following'. And they go, 'Well, actually, we probably should if we want to keep this industry within our country'. So that can be really powerful. But one letter from one retailer to a government is not going to have any effect at all. So I do think collaboration is really important. ${ }^{31}$

Even with such collective leverage of brands, however, advocacy vis-à-vis state actors and entrenched interests has its limits. The most telling example of this in Bangladesh is how the Court kept postponing the decision on whether to extend the Accord beyond 2018. While a compromise was eventually reached to replace the Accord with a new safety entity governed by the industry association, brands and trade unions, the whole process embodied the tug-ofwar between the Bangladeshi government and factory owners on one hand, and a coalition of brands on the other.

Meanwhile, there is a growing interest in lobbying buyers' home-country governments to strengthen regulation, which is another type of advocacy. A number of brand representatives mentioned the need to 'level the playing field' to make sure their competitors do not 'undercut' their efforts. Some brands are more proactive in lobbying for stronger legislation while others are more passive. One slightly up-market brand said they are in favour of regulation as it will make other brands more expensive. ${ }^{32}$ Regulation may also help to convince internal sceptics within buying companies when CSR managers try to make their

\footnotetext{
${ }^{30}$ CSR Manager, UK Firm 02, interview 21 September 2016.

${ }^{31}$ CSR Manager, UK Firm 07, interview 20 February 2017.

${ }^{32}$ CSR Manager, German Firm 05, interview 3 June 2016.
} 
case. When asked whether the UK Modern Slavery Act was a good thing, one brand responded as follows:

I think it's a good thing if we're - I guess at [company name] we've always tried to do things to a certain level and some of the pushback that you sometimes get from other parts of the organization is when you have competitors who are not operating at the same level .... Government legislation lifts everybody up to a certain base level. It makes it a much more even playing field. The Modern Slavery Act, you could actually choose to do nothing with it as long as you made it clear that you weren't doing anything in your statement that you make. But the consumers are not going to be impressed with any business that is doing nothing to address slavery in their business or supply chain. So yeah, I think there's a role to play.

\section{BUYER RESPONSIBILITY AND POWER ACROSS THE THREE APPROACHES}

The main three approaches (auditing, capacity building and advocacy) and the different types we have identified within these approaches are summarized in Table 2. For example, auditing can be conducted by internal or external auditors, but a potentially more important distinction is whether the design of the auditing system is individual or collective. Three components of auditing are standards, audits and enforcement. Traditional social auditing has individual standards (CoCs), individually hired auditors (in-house or external), and enforcement by individual buyers. This is the most criticized form of social auditing. Brands themselves are well aware of the limitations, as illustrated above. Nonetheless, the practice continues because it gives buyers some assurance and guidelines at a manageable cost.

[Table 2 about here]

Despite much hype and excitement surrounding the Accord, it is essentially an auditing approach, complemented by training. It can be distinguished from many other auditing approaches because its design incorporates common standards, common audit platforms and, more importantly, collective enforcement. While some third-party auditing systems have common standards and common audits (e.g. Amfori BSCI, Better Work), enforcement is usually on an individual basis, in the sense that violations can affect sourcing from a single 
buyer. Thus, what really sets the Accord apart from other auditing initiatives is collective enforcement in the form of the threat of withdrawal from over 200 participating buyers.

However, auditing is just one of many activities that global buyers may be engaged in to promote better labour conditions in their supply chains. While few brands actually shoulder the cost of remediation, more are willing to invest in capacity-building programmes (in-house or external) covering a range of issues. While the main mandate of the Accord is auditing, it also carries out training for managers and workers. This can be considered as collective capacity building, where buyers pool resources and let one programme carry out training for their shared suppliers. Brands see capacity building as more promising than auditing in tackling a range of deeper issues such as worker empowerment. Moreover, talking about these initiatives in CSR reports makes them look good. Nonetheless, not all buyers invest in capacity-building initiatives and when they do, they tend to target their strategic suppliers only, limiting their reach and impact.

The least documented activity type is advocacy. We have identified ad hoc (e.g. letter writing, boycotts) as well as more institutionalized forms of advocacy (e.g. ACT), which can be individual but are increasingly shifting to collective. The advantage of advocacy is its potential to address industry-wide issues at a political level, which can lead to sweeping changes. Besides, showing that brands care by signing letters and talking to government officials is seen as a good PR gesture. Nonetheless, effective advocacy vis-à-vis powerful actors requires size, clout and local presence, which is not always possible. Moreover, there are limits to what buyers can do in the face of a recalcitrant government and entrenched interests, as the extreme difficulty of extending the Accord attests.

Examining the three approaches of buyer engagement shows that buyers are consolidating power by exploiting collective leverage vis-à-vis suppliers and political actors. The basis of power lies in brands' ability to shift, or to continue sourcing, from the factory or country. While brands are increasingly exploiting their collective leverage, such growing buyer power has not necessarily been accompanied by greater buyer responsibility. One of the thorniest questions relates to wage issues. Although brands may publicly support higher wages, such statements have rarely translated into higher prices paid to factories (Oka, 2018). Indeed, prices and margins have been falling in the Bangladeshi garment sector (Anner, 2019). This lack of shared responsibility is a problem not just for supplier factories, workers and 
producing countries, but also for buyers themselves as they try to bring about positive changes at the industry level. For instance, although ACT, the latest example of collective advocacy, requires member brands to ring-fence labour costs and to continue sourcing from the country in question, these buyer commitments come into force only when industry-level collective bargaining is actually concluded in the country, which has not yet happened. Given brands' questionable track record of keeping their pledges, government officials and industry associations are deeply sceptical of new and bolder initiatives such as ACT.

A key here is to understand the mixed effects buyers have on labour conditions on the one hand, and the heterogeneity of buyers and their constraints on the other. Kabeer (this issue) shows that factories in Bangladesh which sell to European and American buyers have better social outcomes. At the same time, however, buyers' power and sourcing practices have been identified as the main obstacle to improving labour conditions. Indeed, Anner (2019) argues that buyer consolidation and a 'sourcing squeeze' contributed to substandard working conditions and safety issues, culminating in the Rana Plaza disaster.

While brands are reluctant to discuss their responsibility to pay higher prices to factories or change sourcing practices, they do talk about different kinds of responsibility and pressures they are facing. Several firms, particularly German retailers, mentioned that they have a responsibility toward low-income consumers to keep supplying cheap products and they are facing cut-throat competition. Such views appear to be more prominent in Germany, where online retailers and discounters are major players and price competition is incredibly fierce. Nonetheless, market pressure - especially from online retailers — is also threatening high street brands and retailers in the UK and Sweden, even leading to bankruptcies in some cases.

In the context of such competitive market pressures, when these firms are compelled to play a more active role in improving labour conditions in the factories and countries from which they source, this can create internal tensions between departments tasked with CSR responsibilities and those whose focus is on meeting profit targets (Ashwin et al., 2019). Moreover, even well-intentioned firms struggle to coordinate different functions within the organization. Amengual et al. (forthcoming) use micro-level purchase data to show that even retailers with a strong reputation for social sustainability fail to integrate compliance into sourcing decisions. Furthermore, different buyers are acting in different ways, with some leading, others following and the rest free-riding. Some leading brands appear to be 
exasperated, saying that even they cannot afford to shoulder the whole burden, calling for public regulation to level the playing field.

While the three sets of activities we have discussed have potential to improve labour conditions, buyers' responsibility fundamentally has to include self-regulation and selfalignment as well. Despite the aforementioned challenges, buyers need to review their sourcing behaviour that pushes down prices and shortens lead times, which are currently used — paradoxically — alongside extensive investments in programmes designed to pull conditions up.

\section{CONCLUSION}

The Rana Plaza disaster has led to soul-searching and experimentation with new approaches within the garment industry. This article has identified three approaches (auditing, capacity building and advocacy) and the emerging trend of exploiting collective leverage of buyers. Using empirical research, we have illustrated how buyers perceive the merits, challenges, power and responsibility involved in these activities aimed at improving labour conditions in their supply chains.

Our contributions to the literature are threefold. First, we contribute to the emerging body of work looking at the significance of the Accord (or lack thereof) from buyers' perspectives. We have shown that the Accord is essentially an auditing approach but, crucially, with collective enforcement. Brands have 'discovered' their collective leverage through the Accord and come to exploit it in the Accord process and beyond. On the other hand, buyers' enhanced leverage has not been matched by greater responsibility. Few brands assist supplier factories in their remedial efforts through increased orders or higher prices, while even fewer share the cost of Accord-related remediation. While this is in line with existing studies which point out the lack of shared responsibility (e.g. Barrett et al., 2018; Scheper, 2017), we have argued that the Accord is only one of many activities buyers are engaged in, and that we need to take a holistic view to better understand buyers' perspectives, motivations and constraints.

Second, we map a set of buyer activities covering not only auditing and capacity building, but also the often neglected element of advocacy, identifying merits and demerits of each 
approach. The literature has often contrasted the compliance-oriented auditing approach with the collaboration-commitment approach (e.g. Locke et al., 2009; Lund-Thomsen and Lindgreen, 2014) but overlooked the advocacy role of buyers. We have built on Oka's (2018) work on brand advocacy and identified different types, merits and constraints. Moreover, we raise issues concerning the promise of capacity building to transform the industry, given its limited uptake among brands and lack of willingness to invest beyond pilot projects. Future research could consider the circumstances to which each of these approaches is best suited (Alexander, 2019b; Oka et al., 2019).

Third, we paint a more nuanced picture of global buyers, who are far from homogeneous and monolithic, speaking to the emerging work on different groups of buyers engaging in collective initiatives such as the Accord and ACT (Ashwin et al., forthcoming; Huber and Schormair, 2019). Our study suggests that firm size, market segment and market pressure are important influences on the kind and extent of activities that buyers engage in, with larger and more visible brands taking the lead. Faced with free-riders in the industry, some leading buyers are calling for more regulation. Such calls from progressive businesses may lie behind the recent growth of national legislation in some buying countries (e.g. France, the Netherlands) obliging multinationals to disclose how they are addressing human rights risks in their global supply chains.

Proposed solutions to the problem of poor labour conditions in supply chains seem to converge on sharing. Scholars have called for shared problem solving (Locke et al., 2009), creating shared value with stakeholders (Soundararajan and Brown, 2015), shared responsibility (Barrett et al., 2018), and joint liability (Anner et al., 2013), urging buyers to share their power, knowledge and value. While agreeing with all the above, we emphasize the need to share the burden across all buyers and not just a few leading buyers. Indeed, it is important to recognize the limits of buyer engagement, given that only a subset of buyers voluntarily opt in (Ahlquist and Mosley, 2018). In this sense, the circle is beginning to close, as corporations - which have been outsourcing production to less regulated environments are starting to call for greater public regulation to level the playing field so that all businesses will be compelled to assume greater responsibility. 
Figure 1. Apparel Retail Distribution for Germany, Sweden and the UK, 2017

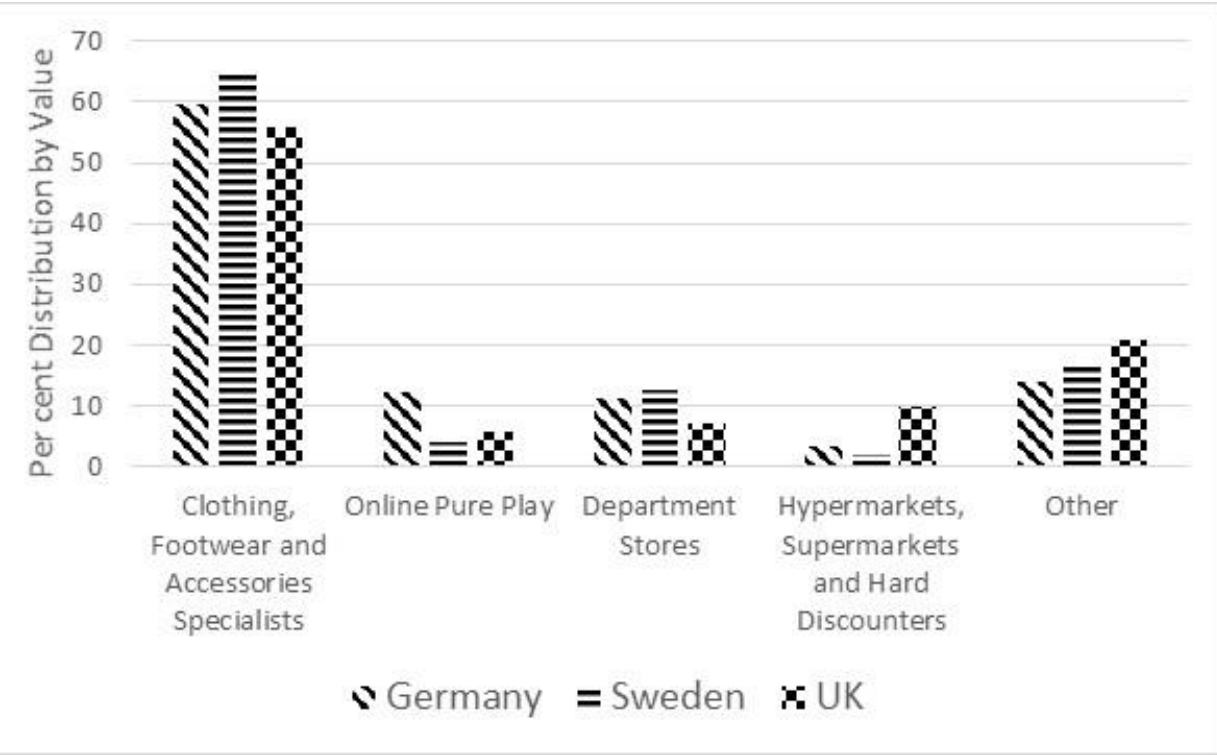

Sources: Marketline (2018a, 2018b, 2018c)

Table 1. Top 5 Sourcing Locations for each Country in 2018

\begin{tabular}{|l|l|c|l|c|l|c|}
\hline & $\begin{array}{l}\text { Sources for } \\
\text { Germany }\end{array}$ & $\begin{array}{c}\text { Value } \\
\text { (US\$ } \\
\text { million) }\end{array}$ & $\begin{array}{l}\text { Sources for } \\
\text { Sweden }\end{array}$ & $\begin{array}{c}\text { Value } \\
\text { (US\$ } \\
\text { million) }\end{array}$ & $\begin{array}{l}\text { Sources for } \\
\text { the UK }\end{array}$ & $\begin{array}{c}\text { Value } \\
\text { (US\$ } \\
\text { million) }\end{array}$ \\
\hline 1 & China & 6,940 & China & 659 & China & 3,736 \\
\hline 2 & Bangladesh & 4,652 & Germany & 373 & Bangladesh & 2,483 \\
\hline 3 & Turkey & 2,781 & Bangladesh & 351 & Turkey & 1,298 \\
\hline 4 & Italy & 1,381 & Denmark & 282 & Italy & 1,088 \\
\hline 5 & India & 1,253 & Netherlands & 152 & India & 1,018 \\
\hline
\end{tabular}

Source: UN Comtrade online database: https://comtrade.un.org/ [7/22/2019] 
Table 2. Three Approaches of Buyer Engagement

\begin{tabular}{|l|l|l|l|}
\hline & \multicolumn{1}{|c|}{ Auditing } & \multicolumn{1}{|c|}{ Capacity Building } & \multicolumn{1}{c|}{ Advocacy } \\
\hline Types & $\begin{array}{l}\text { In-house vs. external } \\
\text { Individual vs. collective }\end{array}$ & $\begin{array}{l}\text { In-house vs. external } \\
\text { Individual vs. collective }\end{array}$ & $\begin{array}{l}\text { Ad hoc vs. institutionalized } \\
\text { Individual vs. collective } \\
\text { Producing vs. buying country }\end{array}$ \\
\hline Examples & $\begin{array}{l}\text { CoC audits, Accord, } \\
\text { Alliance, Amfori BSCI, } \\
\text { Better Work }\end{array}$ & $\begin{array}{l}\text { In-house programmes, } \\
\text { BSR HerProject }\end{array}$ & $\begin{array}{l}\text { Boycotts, letter writing, } \\
\text { meetings, ACT }\end{array}$ \\
\hline Merits & $\begin{array}{l}\text { Control function, } \\
\text { guideline }\end{array}$ & $\begin{array}{l}\text { Can address a range of } \\
\text { issues } \\
\text { Good PR }\end{array}$ & $\begin{array}{l}\text { Can address industry-wide } \\
\text { issue } \\
\text { Good PR }\end{array}$ \\
\hline Challenges & $\begin{array}{l}\text { Limited effectiveness } \\
\text { High resource intensity } \\
\text { Limited reach and impact }\end{array}$ & $\begin{array}{l}\text { Size, clout and local presence } \\
\text { Difficult to convince } \\
\text { powerful actors }\end{array}$ \\
\hline $\begin{array}{l}\text { Basis of } \\
\text { buyer power }\end{array}$ & $\begin{array}{l}\text { Sourcing from the } \\
\text { factory }\end{array}$ & $\begin{array}{l}\text { Sourcing from the } \\
\text { factory }\end{array}$ & $\begin{array}{l}\text { Sourcing from the country } \\
\text { (vis-à-vis producing country) }\end{array}$ \\
\hline $\begin{array}{l}\text { Buyer } \\
\text { responsibility }\end{array}$ & $\begin{array}{l}\text { Reward good performers } \\
\text { Assist remediation effort }\end{array}$ & $\begin{array}{l}\text { Invest beyond pilot } \\
\text { projects }\end{array}$ & $\begin{array}{l}\text { Deliver on promise (e.g. } \\
\text { price, sourcing) }\end{array}$ \\
\hline
\end{tabular}

Source: Authors' construction

REFERENCES

AFL-CIO (2014) 'Responsibility Outsourced: Social Audits, Workplace Certification, and

Twenty Years of Failure to Protect'. Washington: AFL-CIO.

Ahlquist, J.S. and L. Mosley (2018) 'Firm Participation in Voluntary Regulatory Initiatives:

The Accord, Alliance, and US Garment Importers from Bangladesh'. Chapel Hill: The

University of North Carolina at Chapel Hill.

http://laynamosley.web.unc.edu/files/2018/04/Ahlquist-Mosley-2018.pdf

Alexander, R. (2019a) 'Buyer-driven Governance for Sustainability: Exploring Micro and

Meso Governance in Outsourced Production'. Garment Supply Chain Governance

Discussion Paper Series No. 02/2019. Berlin: Garment Supply Chain Governance Project. 
Alexander, R. (2019b) 'Limits to Buyer-Driven Governance for Sustainability in Global Production Networks", Journal of Business Ethics. https://doi.org/10.1007/s10551-019$\underline{04199-4}$

Alexander, R., S. Ashwin, N. Egels-Zandén and N. Lohmeyer (2019) 'Understanding the Emergence of Supply Chain Governance Institutions in Liberal Market Economies and Coordinated Market Economies'. Paper presented at EGOS 2019, University of Edinburgh, Edinburgh (4-6 July).

Amengual, M., G. Distelhorst and D. Tobin (forthcoming) 'Global Purchasing as Labor Regulation: The Missing Middle', Industrial and Labor Relations Review.

Anastasiadis, S., J. Moon and M. Humphreys (2018) 'Lobbying and the Responsible Firm:

Agenda-setting for a Freshly Conceptualized Field', Business Ethics: A European Review 27(3): 207-21.

Anner, M., J. Bair and J. Blasi (2013) 'Toward Joint Liability in Global Supply Chains:

Addressing the Root Causes of Labor Violations in International Subcontracting Networks', Comparative Labor Law \& Policy Journal 35(1): 1-44.

Anner, M. (2019) 'Squeezing workers' rights in global supply chains: purchasing practices in the Bangladesh garment export sector in comparative perspective', Review of International Political Economy. https://doi-org.ezproxy01.rhul.ac.uk/10.1080/09692290.2019.1625426

Ashwin, S., N. Lohmeyer and E. Schüßler (2019) 'Varieties of Policy-Practice Decoupling regarding Labor Standards in Global Garment Supply Chains: Comparing Lead Firms in Germany and the UK'. Paper presented at SASE 2019, the New School, New York City (27-29 June).

Ashwin, S., C. Oka, E. Schüßler, R. Alexander and N. Lohmeyer (forthcoming)

'Transnational Industrial Relations Agreements: The Potential and Limits of Collective Action in Global Supply Chains', Industrial and Labor Relations Review.

Azmeh, S. and K. Nadvi (2014) 'Asian Firms and the Restructuring of Global Value Chains', International Business Review 23(4): 708-17.

Barrett, P.M., D. Baumann-Pauly and A. Gu (2018) 'Five Years after Rana Plaza: The Way Forward'. New York: NYU Stern Center for Business and Human Rights.

Barrientos, S., G. Gereffi and A. Rossi (2011) 'Economic and Social Upgrading in Global Production Networks: A Paradigm for a Changing World', International Labour Review 50(3-4): 319-40. 
Bartley, T. (2003) 'Certifying Forests and Factories: States, Social Movements, and the Rise of Private Regulation in the Apparel and Forest Products Fields', Politics \& Society 31(3): 433-64.

Coe, N.M., P. Dicken and M. Hess (2008) 'Global Production Networks: Realizing the Potential', Journal of Economic Geography 8(3): 271-95.

Distelhorst, G., J. Hinmueller and R.M. Locke (2017) 'Does Lean Improve Labor Standards? Management and Social Performance in the Nike Supply Chain', Management Science 63(3): 587-900.

Donaghey, J. and J. Reinecke (2018) 'When Industrial Democracy Meets Corporate Social Responsibility: A Comparison of the Bangladesh Accord and Alliance as Responses to the Rana Plaza Disaster', British Journal of Industrial Relations 56(1): 14-42.

Egels-Zandén, N. and H. Lindholm (2015) 'Do Codes of Conduct Improve Worker Rights in Supply Chains? A Study of Fair Wear Foundation', Journal of Cleaner Production 107: $31-40$.

Gereffi, G. and F. Mayer (2005) 'Lecture 3. Globalization and the Demand for Governance', in G. Gereffi (ed.) The New Offshoring of Jobs and Global Development, pp. 39-65. Geneva: International Labour Organization.

Huber, K. and M.J. Schormair (2019) 'Progressive and Conservative Firms in Multistakeholder Initiatives: Tracing the Construction of Political CSR Identities within the Accord on Fire and Building Safety in Bangladesh'. Business \& Society. DOI: https://doi.org/10.1177/0007650319825786

Jenkins, R., R. Pearson and G. Seyfang (2002) Corporate Responsibility and Labour Rights: Codes of Conduct in the Global Economy. London: Earthscan.

LeBaron, G. and J. Lister (2015) 'Benchmarking Global Supply Chains: The Power of the “Ethical Audit” Regime', special issue Review of International Studies 41(5): 905-24. Locke, R. (2013) The Promise and Limits of Private Power: Promoting Labor Standards in a Global Economy. Cambridge, UK: Cambridge University Press.

Locke, R., M. Amengual and A. Mangla (2009) 'Virtue out of Necessity? Compliance, Commitment, and the Improvement of Labor Conditions in Global Supply Chains', Politics \& Society 37(3): 319-51.

Lund-Thomsen, P. and A. Lindgreen (2014) 'Corporate Social Responsibility in Global Value Chains: Where Are We Now and Where Are We Going?', Journal of Business Ethics 123(1): 11-22. 
Marketline (2018a) ‘Apparel Retail in Germany’. Reference Code: 0165-2005. Manchester, London, Sydney, New York: Marketline. https://store.marketline.com/report/ohmf2188-apparel-retail-in-germany/

Marketline (2018b) ‘Apparel Retail in Sweden'. Reference Code: 0181-2005. Manchester, London, Sydney, New York: Marketline.

Marketline (2018c) 'Apparel Retail in the United Kingdom'. Reference Code: 0183-2005. Manchester, London, Sydney, New York: Marketline.

MacCarthy, L. (2017) 'H\&M, Zara Boycott Dhaka Apparel Summit over Worker Treatment Issues', SB 24 February. https://sustainablebrands.com/read/leadership/h-m-zara-boycottdhaka-apparel-summit-over-worker-treatment-issues

Merk, J. (2014) 'The Rise of Tier 1 Firms in the Global Garment Industry: Challenges for Labour Rights Advocates', Oxford Development Studies 42(2): 259-77.

Nadvi, K. (2008) 'Global Standards, Global Governance and the Organization of Global Value Chains', Journal of Economic Geography 8(3): 323-43.

Oka, C. (2010) 'Channels of Buyer Influence and Labor Standard Compliance: The Case of the Cambodian Garment Industry', in D. Lewin, B.E. Kaufman and P.J. Gollan (eds) Advances in Industrial and Labor Relations Vol. 17, pp. 153-183. Bingley: Emerald Group.

Oka, C. (2018) 'Brands as Labour Rights Advocates? Potential and Limits of Brand Advocacy in Global Supply Chains', Business Ethics: A European Review 27(2): 95-107.

Oka, C., N. Egels-Zandén and R. Alexander (2019) 'Beyond Workplace Compliance? Portfolios of Buyer Engagement in Labour Standards in Global Garment Production'. Paper presented at SASE 2019, the New School, New York City (27-29 June).

O’Rourke, D. (2003) 'Outsourcing Regulation: Analyzing Nongovernmental Systems of Labor Standards and Monitoring', Policy Studies Journal 31(1): 1-29.

Raworth, K. and T. Kidder (2009) 'Mimicking "Lean" in Global Value Chains: It's the Workers Who Get Leaned On', in J. Bair (ed.) Frontiers of Commodity Chain Research, pp. 165-89. Stanford, CA: Stanford University Press.

Riisgaard, L., P. Lund-Thomsen and N.M. Coe (2019) 'Multistakeholder Initiatives in Global Production Networks: Naturalizing Specific Understandings of Sustainability through the Better Cotton Initiative', Global Networks. DOI: https://doi.org/10.1111/glob.12251

Russell, M. (2018) 'New Call for Brand Support ahead of Bangladesh Wage Talks', JustStyle 28 August. www.just-style.com/news/new-call-for-brand-support-ahead-ofbangladesh-wage-talks_id134335.aspx 
Ruwanpura, K.N. and N. Wrigley (2011) 'The Costs of Compliance? Views of Sri Lankan Apparel Manufacturers in Times of Global Economic Crisis', Journal of Economic Geography 11(6): 1031-49.

Salminen, J. (2018) 'The Accord on Fire and Building Safety in Bangladesh: A New Paradigm for Limiting Buyers' Liability in Global Supply Chains?', The American Journal of Comparative Law 66(2): 411-51.

Scheper, C. (2017) 'Labour Networks under Supply Chain Capitalism: The Politics of the Bangladesh Accord', Development and Change 48(5): 1069-88.

Schrempf-Stirling, J. and G. Palazzo (2016) 'Upstream Corporate Social Responsibility: The Evolution from Contract Responsibility to Full Producer Responsibility', Business and Society 55(4): 491-527.

Schüßler E., S.J. Frenkel and C.F. Wright (2019) 'Governance of Labor Standards in Australian and German Garment Supply Chains: The Impact of Rana Plaza', ILR Review 72(3): 552-79.

Soundararajan, V. and J.A. Brown (2016) 'Voluntary Governance Mechanisms in Global Supply Chains: Beyond CSR to a Stakeholder Utility Perspective', Journal of Business Ethics 134(1): 83-102.

Soundararajan, V., L.J. Spence and C. Rees (2018) 'Small Business and Social Irresponsibility in Developing Countries: Working Conditions and "Evasion" Institutional Work', Business \& Society 57(7): 1301-36.

Tokatli, N. (2007) 'Networks, Firms and Upgrading within the Blue Jeans Industry: Evidence from Turkey', Global Networks 7(1): 51-68.

Turcotte, M.F., J. Reinecke and F. den Hond (2014) 'Explaining Variation in the Multiplicity of Private Social and Environmental Regulation: A Multi-case Integration across the Coffee, Forestry and Textile Sectors', Business and Politics 16(1): 151-89. 